\title{
MARKETING AND CHANGE MANAGEMENT IN THE SERVICES SECTOR
}

\author{
Dejan Dašić ${ }^{1}$, Predrag Ristić ${ }^{2}$, Miodrag Zlatković ${ }^{3}$ \\ ${ }^{1}$ Faculty of Finance, Banking and Auditing Alfa BK University \\ 23 Faculty of Law, Security and Management Konstantin Veliki, \\ Union-Nikola Tesla University
}

Corresponding: dejan.dasic@alfa.edu.rs

Review article

Received: 12.04.2021; Accepted: 01.06.2021

\begin{abstract}
The service sector is a key driver of the modern economy, but the area of marketing is still not sufficiently researched. Services differ from products in many characteristics, so their planning, organization and control deserve great attention. On the other hand, many marketing experts state that product brands are increasingly taking on elements of services, because customers do not view the product only as a product, but a compilation of products and services that goes with the product. The needs of modern customers are changing rapidly, and innovating services that meet the wishes and expectations of customers is a key issue.
\end{abstract}

Keywords: services, marketing, modern economy, quality.

\section{Introduction}

A service is any activity or benefit that one party offers to another, and which is essentially intangible and is not a consequence of ownership of something. Its production may or may not be tied to some physical object. Exceptional service growth has been one of the main trends in recent years. Many countries have experienced a dramatic increase in the importance of service activities for national economies and for individual consumers, and thus the research of service satisfaction factors is becoming increasingly important. [Djukić et al., 2018] In leading European countries, the US and Japan, more people are employed in services than in all other sectors of the economy combined. The public and private service sector in these countries accounts for $60 \%$ to $70 \%$ of gross domestic production [Jovičević \& Žugić, 2018; Ratković 
\& Dašić, 2018; Phan, 2021]. In international trade, services account for a quarter of the total value. In some countries, service occupations are projected to contribute to all net job increases in the coming period.

With the increase in disposable income, people are increasingly thinking about buying services which until recently they performed themselves, such as washing clothes, preparing lunch (service baking), organizing various celebrations and the like. Another reason for the increase in demand for services is the radical demographic change in the world. Life expectancy, due to various advances in medicine, quality of life, is increasingly being prolonged. [Dašić, 2018] There are more and more old people or people living as singles. Marriages do not last as long as they used to. In addition, more and more married couples and children are working, which increases the number of services they have to ask for. Technology is in unstoppable progress, and with it a large number of technologically advanced products that require additional services (computers, software, cars, etc.). Switching from one country to another, from one continent to another is no longer so difficult and demanding, and thus with the advent of free time and the growth of purchasing power, there are higher demands for travel and tourism. [Dašić, et al., 2020; Dašić, 2016] Urbanization, where the demand for services grows with the increase in population, the environment, where services are clean and do not create a problem for the environment in which we exist, are just some of the reasons that explain the unstoppable growth in the field of services.

According to the Senic [2008, 3-36], family line, the linguistic roots of the concept of services offer interesting explanations. The etymological term "service", "servicing" can be reduced to the French word "service", which is again derived from the Latin word "servire", where in the original meaning it means slavery, servitude. In some later period after that, the term services meant war (military) service. In today's meaning of the word service, the basic idea of unpaid slave labour arose. However, today the term services implies an equal partnership between the provider and the user of the offered service. Many authors start from their premise, so even today there is no generally accepted definition of what services are. The former delimitation of services as an "intangible good" is not entirely satisfactory. All services need products that service them and the products require certain services that accompany those products 
(cars require a range of services from servicing, insurance, etc.).

The service is an invisible, intangible and unique product, its role is to gain the trust of consumers by making the quality of the service, reliability and its experience predictable and imaginable. Since services, unlike products, are intangible, their quality mainly depends on the people involved in the process of providing them. Employees i.e., those who represent the organization for consumers and users are the brand, on the basis of which the brand of the organization is built and positioned.

Thus, when deciding to buy a car, more and more, in addition to the brand, increasingly taken into account is what is the service like, method of delivery, warranty, meaning the quality of services that follow after the purchase of the product. Nevertheless, according to Milenović [2003, 179-180], the most important differences could be the following ones between products and services:

- Services are intangible and products are tangible. Therefore, services cannot be tested and verified before purchase, nor can they be handled as products.

- Services are not inseparable from the provider. Hairdressing, cosmetic, medical and many other services can be performed in direct contact and in direct cooperation of providers and users.

- Services "disappear" quickly. If an airline fails to sell all seats for a particular flight, unsold seats cannot be resold.

- Services may not be subject to ownership after purchase

- Many services are provided by people directly. Therefore, the manner of contact, experience and competence of the service provider are very important for an effective service offer

- Services vary widely in quality because providers differ in their personal characteristics and because some providers may have a "bad day" at the time of service provision. The performance of the service to the customer cannot be subject to precise control as the delivery of products to customers.

\section{Specificity of services}

Numerous authors, of whom Sasser, Olson, and Wyckoff pioneered, identify four characteristics of services 1) intangibility, 2) inseparability, 3) diversity, and 4) transience, where for the term inseparability of services simultaneity is used. There are many other characteristics that have been 
suggested, but are not generally accepted, they are based on observations and stories. Kotler and a group of authors [2007, 626-633], distinguish five key characteristics by which services stand out: intangibility, indivisibility, diversity (variability), short duration (perishability) and lack of ownership.

\section{Intangibility}

Pure services cannot be seen, tasted, touched or smelled before being purchased, which implies that they are intangible. A service is an action, performance, or effort, not an object, device, or thing. Before buying, the buyer of the product can think in detail about the colour, design, characteristics, warranty, etc. of a product and the person who goes for a haircut or massage is not able to see the result before that.

In some services, their intangible nature leads to difficulties in assessment after use, which is a great challenge for service firms to find tangible indicators of service quality. One of the very effective ways to minimize the risk of intangibility is to create a strong, recognizable and respected brand image. When you stay at Hilton hotels, you expect and receive top standardized service.

The famous American Express, a very reputable global brand, is known around the world for its credit cards, as well as travel and financial services. From a fast shipping company, which the American Express was in the 19th century, by the middle of the 20th century it had grown into a company specializing in providing services to passengers, and in the minds of consumers it began to be associated with reputation, security, service, international acceptance, ethics in business and leisure. The accompanying advertisement, which intensified in the 1960s, only strengthened these associations. [Keler, 2008, 275] As it grew and developed, American Express expanded its financial business and relied on the acquired positive image among consumers. Customer service was the most important element of the American Express marketing program, as the management said: "Quality is our only patent protection." The firm has also developed a comprehensive service quality measurement system. Their goal was for employees who provide services to clients to do more than 99 percent of the work without any mistakes.

In addition to internal monitoring, American Express constantly surveyed its customers and merchants with whom it cooperated, by mail or by telephone, to ensure that the level of services was uniform. American Express has developed a 
database that was updated once a week, and contained information about customers, who tracked their spending patterns, age and about 450 other characteristics.

Realistic or imaginary stories and anecdotes about the company, product or company owner also contribute to a better identity and positioning of service brands. The only thing that matters is that these stories and anecdotes are positive and interesting. Storytelling has become increasingly important in corporate life. As a concept, it has even won a good starting position in the debate on how the brand will be shaped in the future. Interesting and positive stories and anecdotes from the life of a company or a service provided by that company are easily passed on to end consumers and the general public. Good stories are then retold widely.

\section{Indivisibility}

An important feature of services is that services are produced and consumed at the same time and cannot be separated from their providers, whether the providers are humans or machines. Unlike physical products, services are characterized by indivisibility, i.e., they produce and use at the same time. We first produce physical goods, then store them, then sell them, and only at the end the customer consumes them, while the order of services is reversed, they are first sold and then produced and consumed at the same time.

According to Senić, one of the defining characteristics of inseparability is the physical attachment to the service provider. Another characteristic is that the customer is involved in the production process, further, the presence of other customers during the service meeting. As one of the final obstacles, he mentions the question of how to successfully mass produce the service, i.e., how can a service provider produce enough services to meet mass market demand?

One of the possible solutions to the problem of indivisibility of services is the adequate selection and quality training of staff. This option minimizes the impact of indivisibility by hiring and educating employees resulting in customer satisfaction. "The effectiveness of the organization, which is reflected in the organization's ability to provide products or services that will meet the needs of consumers, is crucial for its survival. These products or services are provided by partial (or complete) people. Employees are not just one of the firm's most important resources; they are also among the most expensive and sometimes the most 
problematic resources". [Jovanović et al., 2004, 5]

The next possible way to solve this problem is to manage customers and service quality. The quality of the service significantly accelerates the decision to repurchase the service. It largely depends on the interaction between the provider and the recipient of the service. The author of this text, at the very moment of writing these lines, experienced that the seller in one shop, addressed him with "may I help you", without looking in his direction, and continued the conversation with another person. Further, firms can use a location strategy in multiple places, which reduces the distance a customer must travel to purchase a service. Due to the simultaneity of production and consumption of services, service providers face special difficulties when demand increases.

According to Kotler [2007, 623], there are several strategies for solving this problem. First, the service provider can learn how to work in larger groups so that it serves multiple consumers at the same time. Second, the service provider can learn how to speed up the work. Finally, a service organization can train more service providers.

\section{Diversity}

The diversity of services means that the quality of services depends on who provides them, as well as the time-when, places-where and manners-how they are provided, which implies that it is very difficult to control the quality of services.

Service organizations can undertake three tasks for quality control. [Rakić, 2008, 460-461] The first task is to invest in hiring good staff and training them. This is of great importance, whether they are very capable professionals or less capable workers.

Another task is to standardize the process of providing services throughout the organization. Assistance in this process is the $\mathrm{de}^{-}$ velopment of a schematic service delivery plan, which outlines the process with objectives and possible critical points. The positive side of standardization is that it leads to lower prices for consumers, consistency of performance and faster delivery of services. However, many believe that standardization neglects the needs and desires of individual customers and that service firms are trying to distance themselves from their customers by increasingly replacing human labour with machinery. 
The third task is to monitor consumer satisfaction, through a system of suggestions, complaints and surveys.

It is common for us to be sold drinks, coffee, tea, food or sandwiches in cafes and bars. While the Internet was still a novelty and was not available to everyone, someone came up with the idea to provide access to the network in the cafe and thus established a new type of cybercafé business.

Cyber cafés are places where you may or may not have to pay for what you drink, but you have to pay for the time you spend in them. A computer connected to the Internet is available at the table where the guest drinks. He can surf, send and receive emails, or chat. Now it is no longer necessary to have someone to go out for a drink with. You can go alone. Order coffee and talk to someone online. [Kotler \& Trias de Bes, 2005, 69]

Gas stations were initially traditional places where people refuelled their cars. However, a decade ago, gas stations expanded the variety of their services to include food, beverages, videotapes, magazines, and even the sale of cameras and cars themselves.

Kotler also lists several steps to address the problem of diversity. One of the possible solutions is to invest in staff recruitment and training programs. The second step towards quality control is to motivate the staff, with the help of incentives for workers who stand out and rewarding the excellent work. The third mechanism for improving quality is to make service staff more visible and responsible to consumers, car dealers often allow consumers to talk directly to mechanics working on their vehicles. Finally, as a possible solution, he states that service companies can increase the consistency of worker performance by replacing staff with equipment and standardizing the service work process throughout the organization. This is achieved by drafting services, outlining events and processes or business procedures in a flowchart, which draws workers' attention to places, potential omissions.

\section{Perishability}

Services cannot be stocked for later sale or distribution. Failure to appear at the driving test, or at the college exams is charged, because the value of the services existed only in that term and disappeared when the candidate did not appear.

To match supply and demand for services, companies can apply several strategies. Possible strategies on the demand side are: 
- Different prices - i.e., charging different prices at different time intervals, or periods when demand needs to be improved in weaker periods.

- Reservations - is one of the ways to manage the level of demand and is used by restaurants, hotels, airlines, doctors and many others.

- Complementary services - during rush hours as an alternative to waiting customers, such as when banks provide an automatic money counting machine to serve customers, reading newspapers while you wait in the dentist's office, etc.

According to Senić [2008, 34], there are some exceptions, which concern the generalization related to the instability and storage of services. In insurance, for example, a service is purchased. It is kept with the insurance organization (seller) until the occurrence of the insured event, while the buyer does not need it. This holding is a type of storage. When a work performance can be stored on media (floppy disks, paper, CDs or books), it can thus be stored and made marketable. Certainly, only after the production of these effects these are services, and after that they belong to the physical goods. Some service companies may store part of their service process for a limited time.

\section{Lack of Ownership}

According to Kotler, in addition to the four characteristics standardized so far, he also introduces a fifth characteristic, which is the lack of ownership. He states the reason is that when customers buy physical goods such as a car or a computer, it becomes available to them personally for an unlimited time, and on the contrary, service products do not have such a characteristic. The insurance policy is yours only as long as you pay the premium.

Due to the lack of ownership, service providers must make a special effort to strengthen the identity of their brands and consumer preferences, using one or several methods [Kotler et al., 2007, 633].

\section{Service differentiation management}

With great efforts, quality management has reached the level that only a small number of universities treat it as a special science. It originated in the USA, developed in Japan and Europe. Today, it can be said that quality management has become inevitable and has conquered the world. [Vojnović, 2008] The diversity and growth of new services is evident. Thus, after Austin, Ulm and Hamburg, the new type of "Car2go" service system will come to life in Amsterdam, 
whose streets will have 300 "Smart fortwo" electric models by the end of 2011. The plan is to expand the fleet by at least another 700 cars in 2012, because everyone is convinced of the success of this service. "Car2go" serves drivers to easily, quickly and cheaply rent cars that will be deployed in the centre of Amsterdam. All you need to do is pay 29 euros for registration, during which you get a card with a chip and a pin code. When you need a car, all you have to do is open the "Smart" and type in the pin code. The key is in the car, and the use is charged per minute, which, say in Hamburg, costs 29 euro cents. The price of a minute includes everything, from rent and fuel, through parking to taxes. If you no longer need the car, just park it, and the rental amount will be deducted from your account.

For example, British Airways has offered business and first-class passengers sleeping cabins, hot showers and a la carte breakfast. Virgin Atlantic Airways, to differentiate its offering, was among the first to offer innovations such as in-flight movie selections, ergonomic seats, air-to-ground telephone connections and frequent-flyer awareness programs. Virgin Atlantic has also introduced folding seats in business class, which can be turned into beds. The ability to provide these additional luxuries to business travellers has put the two airlines in a comfort dimension far ahead of its competitors. In addition, the Virgin's Upper Class cabin has a private space for beauty treatments and massages. [Kotler et al., 2007, 637]

Differentiation of services reveals another problem, and that is that innovations in services cannot be patented and are very often subject to copying, which implies various ethical controversies. The diversity of services implies that it is difficult to control standardization and quality. It is difficult to reach the set quality frameworks. Service companies can differentiate from other companies in three ways:

- through people themselves,

- the environment and

- the processes

\section{Branding services with quality and productivity}

This is one of the ways in which a company can be different from others. In the Scandinavian countries, and especially in Sweden, service quality management is a task of national importance, in which the government is also at the forefront, through incentives such as the Swedish customer satisfaction barometer. Elsewhere, as in the UK, local authorities or councils are also under increasing pres- 
sure to provide quality services to the local communities they serve. One of the most concise definitions of quality is: "Quality is the measure by which a product meets customer requirements". [Senić \& Senić, 2008, 444]

Productivity is a measure of the relationship between invested funds. For example, if more people can be served (result) using the same number of staff (invested), then productivity per employee is higher. The most commonly accepted measurement scale for measuring service quality is the SERVQUAL instrument. The SERVQUAL model is a quantitative model for measuring the quality of services in the field of tourism. This model is based on measuring the difference between "what consumers/customers want" and "what consumers/customers get". Knowledge of instruments for measuring the quality of services is important because in this way it can effectively influence the improvement of the quality of tourist services and tourist satisfaction, as well as the improvement of economic performance in the field of tourism. [Gašević et al., 2019]

Improving productivity is important for several reasons:

First, it helps keeping the costs low. Lower costs mean significantly higher profits or the ability to keep prices low. The company with the lowest costs in the branch has the opportunity to position itself as a leader in low prices - which is usually a significant advantage among segments that are consciously valued. Second, firms with lower costs also realize higher margins, which offers these firms the option to spend more than competitors on marketing activities, customer service improvements, and additional services. Such firms may also offer higher margins to attract and retain the best distributors and intermediaries. The third option is to ensure the long-term future of the firm through investment in new service technologies and research to create superior new services, improve features and innovative service delivery systems. Finally, efforts to improve productivity often have an impact on customers. Vendors are responsible for ensuring that negative impacts are avoided or minimized, and that new procedures are carefully presented to customers. Positive impact can be promoted as a new advantage.

\section{Conclusion}

Contemporary economic trends have a drastic impact on the lifestyle and behaviour of customers and consumers. Therefore, giving greater values to customers is even more important today, be- 
cause companies that have invested heavily in their brand of services will find it much easier to get through these difficult times. Their deep understanding of customers allows them the flexibility to tailor their service offering that is relevant to customers. The way to success for the service companies is linked to the intensity and efficiency of the 'moment of truth' where employees and customers are put together in the transaction. It's at that real moment of delivery that satisfaction, retention and engagement of both parts are build up. The better this moment is managed, the more the 'wheels' are

\section{References}

Dašić D. (2018) Menadžment zdravstvenog i medicinskog turizma - mogući pravci razvoja u Republici Srbiji, Ekonomski signali, Vol. 13., br 1. 41-56

Dašić, D. (2016). Brendiranje mesta i/ili destinacija, Kultura, br. 152, 377-393.

Dašić D., Živković D. \& Vujić T. (2020) Rural tourism in development function of rural areas in Serbia. Economics of Agriculture, Year 67, No. 3, 719-73

Đukić, S., Đorđević, B. \& Berber, N. (2018), Uticaj ponašanja zaposlenih na percipirani kvalitet usluge. Marketing, 49 (1), 18 29. turning on and the more solid the relation and confidence growths up. [Phan, 2021] The needs of modern customers are changing rapidly, and innovating services that meet the desires and expectations of customers is a key issue. For some, the way forward is growth through building relationships through partnerships and strategic alliances, for others product differentiation from others and quality. Overall, the general conclusion is that only companies that apply a holistic approach to service branding have the advantage and ability to provide greater value to their customers in the future.

Gašević D., Vranješ M. \& Tomašević D. (2019) Kvalitet usluga u funkciji zadovoljstva potrošača. Ekonomija teorija i praksa, God. XII, br. 2,45-53

Jovanović, M. (2004) Human Resources Management, Megatrend, Belgrade.

Jovičević, R. \& Žugić, J. (2018). Marketing u savremenom bankarstvu, Podgorica, Univerzitet Mediteran.

Kotler, F., Vong, V., Sonders, Dž. \& Armstrong, G. (2007). Principi Marketinga, četvrto evropsko izdanje, Mate, Beograd. 
Keler, K.L. (2008) Slučajevi najbolje prakse $u$ brendiranju lekcije od najačih svetskih brendova, Mass Media, prvo izdanje, Beograd.

Kotler, F. \& Trias De Bes, T. (2005) Lateralni Marketing-tehnike za iznalaženje novih ideja, Adižes, Novi Sad.

Phan T.T. (2021)- Fundamentals in service marketing http://cdvf.free.fr/phantu/study/is cid/service_marketing.pdf (22.6.2021)

\footnotetext{
${ }^{1}$ https://orcid.org/0000-0002-8245-1117
}

Rakić, B. (2008) Marketing, 5-ediion, Megatrend, Belgrade.

Ratković, M. \& Dašić, D. (2018), Marketing $u$ sportu, Visoka škola modernog biznisa, Sven, $\mathrm{Niš}$

Senić, R. \& Senić, V. (2008). Menadžment i Marketing usluga, Prizma, Kragujevac.

Vojnović, B. (2008) Upravljanje kvalitetom usluga. Ekonomske teme, God. XLVI, br. 3, 181-194 


\section{MARKETING I UPRAVLJANJE PROMENAMA U SEKTORU USLUGA}

\section{Dejan Dašić ${ }^{1}$, Predrag Ristić ${ }^{2}$, Miodrag Zlatković ${ }^{3}$}

${ }^{1}$ Fakultet za finansije bankarstvo i reviziju Alfa BK Univerzitet

${ }^{2} 3$ Fakultet za pravo bezbednost i menadžment Konstantin Veliki,

Univerzitet Union Nikola Tesla

Korespondencija:dejan.dasic@alfa.edu.rs

Rezime: Sektor usluga je ključan pokretač saremene ekonomije, ali još uvijek nije dovoljno istraženo područje u marketingu. Usluge se po mnogim karakteristikama razlikuju od proizvoda, pa stoga njihovo planiranje, organizovanje i kontrola zaslužuju veliku pažnju. Sa druge strane, mnogi marketinški stručnjaci navode da brendovi proizvoda sve više poprimaju elemente usluga, jer kupci ne posmatraju proizvod samo kao proizvod, već jednu kompilaciju proizvoda i usluga koji ide uz proizvod.

Ključne reči: usluge, marketing, savremena ekonomija, kvalitet 
